\title{
Pharmacogenetics of Tardive Dyskinesia: Combined Analysis of 780 Patients Supports Association with Dopamine D3 Receptor Gene Ser9Gly Polymorphism
}

Bernard Lerer, M.D., Ronnen H. Segman, M.D., Heiner Fangerau, M.D., Ann K. Daly, Ph.D.

Vincenzo S. Basile, B.Sc., Roberto Cavallaro M.D., Harald N. Aschauer M.D.,

Robin G. McCreadie, M.D., Stephanie Ohlraun, M.Psych., Nicol Ferrier, M.D., Mario Masellis M.Sc., Massimiliano Verga, M.D., Joachim Scharfetter, M.D., Marcella Rietschel, M.D., Roger Lovlie, Ph.D., Uriel Heresco Levy, M.D., Herbert Y. Meltzer, M.D., James L. Kennedy, M.D., Vidar M. Steen, Ph.D., and Fabio Macciardi, M.D., Ph.D.

Variability among individuals in their therapeutic response to psychotropic drugs and in susceptibility to adverse effects is considerable. Pharmacogenetics addresses the contribution of genetic factors to this variability. An important focus of interest in pharmacogenetics has been on candidate genes that play a role in susceptibility to the antipsychotic drug-induced adverse effect, tardive dyskinesia (TD). Four published studies have reported an association between a serine (ser) to glycine (gly) polymorphism in exon 1 of the dopamine D3 receptor gene (DRD3) and TD; three failed to replicate this finding and one found an insignificant trend. We examined the association in a pooled sample of 780 patients (317 with TD and 463 without TD) drawn from 6 research centers, who were divided into 8 groups based on their population origin. The analysis employed stepwise logistic regression so as to

From the Biological Psychiatry Laboratory, Department of Psychiatry, Hadassah-Hebrew University Medical Center, Jerusalem, Israel (BL, RHS); Department of Psychiatry, University of Bonn, Bonn, Germany (HF, SO, MR); Deptartment of Pharmacological Sciences, University of Newcastle upon Tyne, Newcastle, UK (AKD); Department of Psychiatry, Centre for Addiction and Mental Health, Clarke Division, University of Toronto, Toronto, Canada (VSB, MM, JLK, FM); Department of Psychiatry, IRCCS H San Raffaele, Universitat Vita e Salute, Milan, Italy (RC, MV); Department of General Psychiatry, University Hospital for Psychiatry, Vienna, Austria (HNA, JS); Department of Clinical Research, Crichton Royal Hospital, Dumfries, UK (RGM); Department of Psychiatry, University of Newcastle upon Tyne, Newcastle, UK (NF); Dr. E. Martens Research Group for Biolog- allow confounding effects of group, age, and gender to be taken into account. TD was significantly associated with DRD3 gly allele carrier status $\left(x^{2}=4.46, d f 1, \mathrm{p}=.04\right)$ and with DRD3 genotype ( $x^{2}=6.62$, df $\left.2, \mathrm{p}=.04\right)$ over and above the effect of group. Similar positive effects were observed when controlling for age and gender $\left(x^{2}=5.02, d f\right.$ $1, \mathrm{p}=.02$ for gly allele carrier status; $x^{2}=7.51$, df $2, \mathrm{p}=$ .002 for genotype). Examining abnormal involuntary movement scores as a continuous variable, we found that patients homozygous for the gly allele had significantly higher scores than ser-gly heterozygotes $(\mathrm{p}=.006)$ or serser homozygotes ( $\mathrm{p}<.0001)$. We also performed a metaanalysis that included, besides the groups in the combined analysis, three other published studies on DRD 3 and TD. The Mantel-Haenszel pooled odds ratio for DRD3 gly allele carrier status increasing susceptibility to TD was 1.33

ical Psychiatry and Locus on Neuroscience, Center for Medical Genetics and Molecular Medicine, Haukeland University Hospital, University of Bergen, Norway (RL, VMS); Sara Herzog Memorial Hospital, Jerusalem, Israel (UHL); Vanderbilt University Medical Center, Psychiatric Hospital at Vanderbilt, Nashville, TN, USA (HYM).

Address correspondence to: Prof. Bernard Lerer, Director, Biological Psychiatry Laboratory, Department of Psychiatry HadassahHebrew University Medical Center, Ein Karem, Jerusalem 91120, Israel. E-mail: lerer@cc.huji.ac.il

Received September 20, 2001; revised January 9, 2002; accepted January 17, 2002.

Online publication: $1 / 21 / 02$ at www.acnp.org/citations/ Npp012102229. 
(95\% CI 1.04-1.70, $\mathrm{p}=.02)$; the cumulative pooled estimate showed an odds ratio of 1.52 (95\% CI 1.08-1.68, $\mathrm{p}<.0001)$. These findings support a small but significant contribution of the DRD3 serggly polymorphism to TD susceptibility that is demonstrable over and above population effects and the effect of age and gender on the phenotype.

[Neuropsychopharmacology 27:105-119, 2002]

(C) 2002 American College of Neuropsychopharmacology. Published by Elsevier Science Inc.
KEY WORDS: Antipsychotic drugs; Dopamine D3 receptors; Molecular genetics; Pharmacogenetics;

Pharmacogenomics; Tardive dyskinesia; Schizophrenia; Single nucleotide polymorphism

Currently, there is considerable interest in the application of emerging genomic technologies to the clinical practice of psychopharmacology (Catalano 1999; Veenstra-VanderWeele et al. 2000; Cichon et al. 2000; Pickar and Rubinow 2001; Lerer, in press). Variability among individuals in their degree of response to psychotropic drugs and in susceptibility to adverse effects is considerable. It is widely assumed that a substantial portion of this variability is genetically determined. Based on this assumption, identification of the genes involved and of pharmacogenetically relevant variation in their structure is regarded as an important research priority. The emphasis has been on functionally significant genetic variants, most often single nucleotide polymorphisms (SNPs) located in coding or regulatory regions of candidate genes that have a priori relevance to the drug response or adverse effect phenotype under study. SNPs located in intronic regions, however, can also have an impact on the coded protein (Krawezak et al. 1992). Although genetic factors that influence drug metabolism were studied in psychopharmacology long before current genomic technology was available (Poolsup et al. 2000; Steimer et al. 2001), work on pharmacodynamic aspects is still at an early stage. It has focused primarily on response to specific serotonin reuptake inhibitors (SSRIs) in major depression (Smeraldi et al. 1998, Lerer and Macciardi in press) and to atypical antipsychotic drugs, primarily clozapine, in schizophrenia (Arranz et al. 1998, Scharfetter et al. 1999a, Masellis et al. 2000).

An important focus of interest in pharmacogenetics has been on candidate genes that play a role in susceptibility to tardive dyskinesia (TD). TD is a choreoathetotic movement disorder with a chronic fluctuating course that affects $20 \%$ or more of chronic schizophrenia patients who are treated with classical, dopamine D2 receptor antagonist, antipsychotic drugs (Kane and Smith 1982; Jeste and Wyatt 1982; Kane 1995). Age is the strongest-known risk factor for the development of TD (Smith and Baldessarini 1980; Jeste et al. 1995). Other factors include duration and intensity of prior antipsychotic exposure, female gender, organic brain abnormalities, smoking, and affective disorder (Kane and Smith, 1982; Kane et al. 1992; Yassa and Jeste 1992). As demographic and drug-related variables predict only a minor part of the variance in the incidence of TD, a prominent pharmacogenetic component appears plausible. Sporadic clinical reports of aggregation of TD cases in families (Yassa and Ananth 1981; Weinhold et al. 1981; Waddington and Yousseff 1988; Yousseff et al. 1989) and strain differences in the susceptibility of rodents to antipsychotic-induced repetitive jaw movements and vacuous chewing (Rosengarten et al. 1994; Tamminga et al. 1990), provide some support for a genetic predisposition. There are no studies that have explored the possible mode of inheritance of predisposition to TD as a genetic trait. Such studies are very difficult to perform because level of exposure to antipsychotic drugs and the precise drug administered to individual family members cannot be controlled. For the same reason, linkage analyses are not an applicable approach in the search for predisposing genes. Studies of the molecular genetics of TD have thus far employed a case-control association design implemented in samples of unrelated patients.

Attempts to elucidate pharmacogenetic factors in TD are important at two levels. First, in spite of the increasing use of atypical antipsychotic drugs, which have a lesser propensity to induce TD, classical antipsychotic agents are still widely used worldwide (Emsley et al. 1999). Second, TD is a relatively well-defined, semiquantitative phenotype. As a model for pharmacogenetic studies in general, analysis of the molecular genetic basis of individual susceptibility to TD can provide important insights into crucial methodologic and statistical issues that are of general relevance to pharmacogenetics.

A number of genes have been studied as potential contributors to individual sensitivity to TD. These include genes implicated in the metabolism of antipsychotic drugs such as the genes for cytochrome P-450 2D6 (Arthur et al. 1995; Armstrong et al. 1997; Andreassen et al. 1997, Kapitany et al. 1998; Ohmori et al. 1999) and cytochrome P-450 1A2 (Basile et al. 2000), genes coding for the dopamine D2 (Chen et al. 1997) and D3 receptors (see below); serotonergic receptor genes such as the 5-HT2C receptor (Segman et al. 2000) and the 5HT2A receptor (Segman et al. 2001; Basile et al. 2001, Tan et al. 2001), the serotonin transporter gene (Chong et al. 2000), and the manganese superoxide dismutase (MnSOD) gene (Hori et al. 2000). Earlier studies with Human Leukocyte Antigen (HLA) subtypes should also be noted (Canoso et al. 1986; Meltzer et al. 1990; Brown and White, 1991). (See Segman and Lerer, in press, for a review of candidate gene studies in the pharmacogenetics of TD). 
The largest series of studies on candidate genes for TD has focused on the dopamine D3 receptor (DRD3). The human DRD3 gene has been localized to chromosome 3q13.3 by in situ hybridization (Le Coniat et al. 1991). D3 receptors readily bind classic and also atypical antipsychotic drugs but differ from other dopamine receptor subtypes in that they are primarily localized to limbic regions that may be particularly important in the regulation of emotions and in the pathogenesis of schizophrenia (Sokoloff et al. 1990; Zahm and Brog 1992). DRD3 contains a polymorphic site in the first exon that gives rise to a serine (ser) to glycine (gly) substitution in the $\mathrm{N}$-terminal extracellular domain of the receptor protein (Lannfelt et al. 1992). The in vivo functional significance of the polymorphic ser9gly site is unknown. DRD3 receptor-binding analysis of Chinese hamster ovary $(\mathrm{CHO})$ cells infected with Semliki Forest Virus to express either the wild-type cDNA or a recombinant ser9gly or both showed similar pharmacologic properties for several D3 receptor ligands. The cells expressing the DRD3gly variant, however, showed a sig- nificantly higher binding affinity only for dopamine, whereas heterozygotes (i.e., doubly infected cells) were not significantly different from the wild type. In addition, both DRD3gly-gly homozygotes and DRD3ser-gly heterozygotes showed significantly higher binding affinity for the selective D3 ligand GR99841, compared with the wild-type receptor (Lundstrom \& Turpin 1996). Although these results do not allow a straightforward extrapolation with regard to the biological significance of heterozygote versus homozygote status, they speak for either examining DRD3gly-gly homozygotes against all other genotypes or for grouping DRD3glygly homozygotes and DRD3ser-gly heterozygotes against wild-type homozygotes. Such extrapolations should be taken with caution, however, as these results were obtained in an in vitro recombinant system not necessarily reflecting in vivo receptor status in the brain. A clearer understanding of the functional significance of the ser9gly site must await more detailed studies employing in vivo radioligand binding, as well as postmortem brain and in vitro receptor studies.

Table 1. Published studies on the DRD3 ser9gly polymorphism and TD

\begin{tabular}{|c|c|c|c|}
\hline Publication & Subjects & Findings from categorical analysis & Findings from continuous analysis \\
\hline Steen et al. (1997) & $\begin{array}{l}\text { TD-Y: } 51 \\
\text { TD-N: } 49 \\
\text { Origin: Caucasian }\end{array}$ & $\begin{array}{l}\text { Excess of gly allele }(p=.035) \text { in TD } \\
\text { Excess of gly-gly genotypes }(p= \\
\quad .018) \text { in TD }\end{array}$ & Not reported \\
\hline Inada et al. (1997) & $\begin{array}{l}\text { TD-Y: } 49 \\
\text { TD-N: } 56 \\
\text { Origin: Japanese }\end{array}$ & $\begin{array}{l}\text { No significant difference in allele or } \\
\text { genotype frequency }\end{array}$ & Not reported \\
\hline Segman et al. (1999) & $\begin{array}{l}\text { TD-Y: } 53 \\
\text { TD-N: } 63 \\
\text { Control: } 117 \\
\text { Origin: Israeli Ashkenazi } \\
\quad \text { and non-Ashkenazi } \\
\text { Jews }\end{array}$ & $\begin{array}{l}\text { Excess of gly allele }(p=.055) \text { in TD } \\
\text { Excess of ser-gly genotypes }(p= \\
\quad .0008) \text { in TD }\end{array}$ & $\begin{array}{l}\text { Higher AIMS total }(p=.02) \text {, orofacial }(\mathrm{p}= \\
.052) \text {, trunk }(p=. \mathrm{p}=.01) \text {, and } \\
\text { incapacitation }(p=.03) \text { scores in } \\
\text { patients carrying the gly allele (ser-gly } \\
\text { and gly-gly genotypes vs. ser-ser } \\
\text { genotypes) }\end{array}$ \\
\hline Basile et al. (1999) & $\begin{array}{l}\text { TD categorization not } \\
\text { reported. } \\
\text { Origin: Caucasian, } \mathrm{n}= \\
85, \text { African American, } \\
\mathrm{n}=25, \text { Asian, } \mathrm{n}=2\end{array}$ & Not reported & $\begin{array}{l}\text { Higher AIMS total scores ( } p=.0005) \text { in } \\
\text { patients with gly-gly genotypes vs. ser- } \\
\text { ser genotypes and ser-gly genotypes. } \\
\text { (Also in Caucasians and African } \\
\text { Americans analyzed separately) }\end{array}$ \\
\hline Rietschel et al. (2000) & $\begin{array}{l}\text { TD-Y: } 79 \\
\text { TD-N: } 78 \\
\text { Origin: German }\end{array}$ & $\begin{array}{l}\text { No significant difference in allele or } \\
\text { genotype frequency }\end{array}$ & Not reported \\
\hline Lovlie et al. (2000) & $\begin{array}{l}\text { TD-Y: } 32 \\
\text { TD-N: } 39 \\
\text { Origin: Caucasian }\end{array}$ & $\begin{array}{l}\text { No significant difference in allele or } \\
\text { genotype frequency }\end{array}$ & Not reported \\
\hline $\begin{array}{l}\text { Garcia-Barcelo et al. } \\
\quad(2001)\end{array}$ & $\begin{array}{l}\text { TD-Y: } 65 \\
\text { TD-N: } 66 \\
\text { Origin: Chinese (Hong } \\
\text { Kong) }\end{array}$ & $\begin{array}{l}\text { No significant difference in allele or } \\
\text { genotype frequency }\end{array}$ & Not reported \\
\hline Liao et al. 2001 & $\begin{array}{l}\text { TD-Y: } 21 \\
\text { TD-N: } 94 \\
\text { Origin: Chinese (Taiwan) }\end{array}$ & $\begin{array}{l}\text { Allele frequencies not compared. } \\
\text { Excess of ser-gly genotypes }(p= \\
.009) \text { in TD. }\end{array}$ & $\begin{array}{l}\text { Higher AIMS total scores in patients with } \\
\text { ser-gly genotypes compared to patients } \\
\text { with ser-ser and gly-gly genotypes ( } p= \\
.014)\end{array}$ \\
\hline
\end{tabular}


A summary of published studies of the DRD3 gene as a risk factor for TD is given in Table 1. Steen et al. (1997) first reported association of the DRD3 gly allele and TD in schizophrenia patients and observed a significant excess of DRD3gly-gly homozygotes among the patients with TD. The finding of Steen et al. (1997) has subsequently been supported by the observations of Segman et al. (1999), Basile et al. (1999), Liao et al. (2001), and (at a trend level) by Lovlie et al. (2000), but not by Inada et al. (1997), Rietschel et al. (2000), and Garcia-Barcelo et al. (2001). Important differences among these findings should be noted. Whereas the findings of Steen et al. (1997) suggested homozygosity for the DRD3 gly allele as a risk factor for TD, the findings of Segman et al. (1999) pointed to a dominant model and demonstrated an excess of DRD3gly carriers, whether as homo- or heterozygotes, among patients with TD. The findings of Liao et al. (2001) were similar to those of Segman et al. (1999). Basile et al. (1999) did not report a categorical analysis of their data but presented their findings as significantly higher scores on the Abnormal Involuntary Movements Scale (AIMS) (Guy, 1976) in patients homozygous for the DRD3gly allele. Segman et al. (1999) presented their results parametrically as well as categorically, demonstrating significantly higher AIMS scores in patients carrying the DRD3 gly allele as homo- or heterozygotes versus patients homozygous for the wild type ser allele. Liao et al. (2001) also presented a parametric analysis, finding significantly higher AIMS scores in patients carrying the ser-gly genotype compared with carriers of ser-ser or gly-gly. A further point of note is that only Steen et al. (1997), Inada et al. (1997), and Rietschel et al. (2000) based their definition of TD on repeated assessments of abnormal involuntary movements in their patients, thus fulfilling the criteria of Schooler and Kane (1982) for definite TD in regard to the patients categorized as fulfilling the diagnosis.

While suggesting a possible role for DRD3 in conferring genetic susceptibility to TD, the literature leaves a number of crucial questions unanswered or answered only in part. Central among these is whether the observed effects can be generalized among different populations, and whether population differences contribute to the different results obtained. Further issues are the extent to which known risk factors for TD such as age and gender impact son the findings. Noteworthy in this regard, Segman and Lerer (2002) recently found that age might not only influence vulnerability to TD but the contribution of certain genetic polymorphisms to this vulnerability.

In the present article, we present the results of a combined analysis of original data from several published papers on DRD3 and TD. To these we added data from two samples that have been presented in abstract form but not published in full. Our analysis took into account the possible confounding effects of the origin of the patients, differences in the rating of abnormal involuntary movements between centers, and the impact of age and gender in the context of a combined sample that had significantly greater statistical power than the component samples to address the role of DRD3 as a risk factor for TD.

\section{MATERIALS AND METHODS}

\section{Patients}

Demographic, clinical, and genotypic data on the patients included in this analysis were supplied by six research centers: the University of Bergen, Norway; University of Bonn, Germany; Hadassah-Hebrew University Medical Center, Jerusalem, Israel; San Rafaele Institute, Milan, Italy; University of Toronto, Canada; and University of Vienna, Austria. The minimum criteria for inclusion in the analysis were information on age and gender; diagnosis of schizophrenia or schizoaffective disorder according to DSM-IV or ICD-9; presence or absence of TD established according to the Research Diagnostic Criteria for TD (Schooler and Kane 1982) and genotypic status on the DR3D3 ser9gly polymorphism. AIMS scores were available for patients supplied by the Bergen (Newcastle and Nithsdale samples), Bonn, Jerusalem, and Toronto centers. Patients from the Milan center were assessed for abnormal involuntary movement by the Rockland Simpson Scale (Cavallaro et al. 1993), and patients from Vienna by the Tardive Dyskinesia Rating Scale (Simpson et al. 1979). Twenty three patients from Vienna were not assessed for TD with a rating scale; the diagnosis was made on the basis of clinical examination. Key analyses were repeated without these patients, and results did not differ substantively from those reported here (available on request). Because TD ratings were performed twice in only some of the centers, categorization according to presence or absence of TD in the present analysis is based on a single evaluation (the first if there was more than one evaluation). The TD diagnosis is thus at the probable level according to the RDC-TD criteria (Schooler and Kane 1982).

For the current analysis, patients were divided into eight groups regarding which further details are provided below and in Table 2. Data on the Bonn (Rietschel et al. 2000), Jerusalem (Segman et al. 1999), Newcastle (Lovlie et al. 2000), Nithsdale (Steen et al. 1997), and Toronto African American and Toronto Caucasian groups (Basile et al. 1999) had been published previously. Data on the Milan (Macciardi et al. 1996, 1997) and on part of the patients of the Vienna group, included in a larger data set (Scharfetter et al. 1999b), had been reported in abstract form. There were 240 patients from Bonn in the current analysis as compared with 157 
Table 2. Demographic and clinical details of the sample

\begin{tabular}{|c|c|c|c|c|c|c|c|c|c|c|}
\hline \multirow[b]{2}{*}{ Group } & \multicolumn{4}{|c|}{ TD-Y } & \multicolumn{4}{|c|}{ TD-N } & \multirow[b]{2}{*}{ Origin } & \multirow{2}{*}{$\begin{array}{c}\text { TD } \\
\text { assessment }\end{array}$} \\
\hline & $\mathbf{N}$ & Age & Gender & Diagnosis & $\mathbf{N}$ & Age & Gender & Diagnosis & & \\
\hline Bonn & 85 & $44.6 \pm 11.6$ & $\begin{array}{l}\mathrm{F}-41 \\
\mathrm{M}-44\end{array}$ & $\begin{array}{l}\text { SCZ-20 } \\
\text { SA-65 }\end{array}$ & 155 & $39.4 \pm 10.2$ & $\begin{array}{l}\mathrm{F}-86 \\
\mathrm{M}-69\end{array}$ & $\begin{array}{l}\text { SCZ-42 } \\
\text { SA-113 }\end{array}$ & German & AIMS \\
\hline Jerusalem & 55 & $50.8 \pm 10.3$ & $\begin{array}{l}\mathrm{F}-26 \\
\mathrm{M}-29\end{array}$ & SCZ-55 & 58 & $50.8 \pm 10.3$ & $\begin{array}{l}\mathrm{F}-28 \\
\mathrm{M}-30\end{array}$ & SCZ-58 & $\begin{array}{l}\text { Israeli } \\
\quad \text { Ashkenazi } \\
(\mathrm{n}=66) \text { and } \\
\text { non-Ashkenazi } \\
(\mathrm{n}=47) \text { Jews }\end{array}$ & AIMS \\
\hline Milan & 34 & $55.8 \pm 10.4$ & $\begin{array}{l}\mathrm{F}-16 \\
\mathrm{M}-18\end{array}$ & SCZ-34 & 59 & $53.4 \pm 10.6$ & $\begin{array}{l}\mathrm{F}-30 \\
\mathrm{M}-29\end{array}$ & SCZ-59 & $\begin{array}{l}\text { Northern } \\
\text { Italian }\end{array}$ & $\begin{array}{l}\text { Rockland } \\
\text { Simpson } \\
\text { Dyskinesia } \\
\text { Scale }\end{array}$ \\
\hline Newcastle $^{+}$ & 32 & $53.1 \pm 18.0$ & $\begin{array}{l}\mathrm{F}-4 \\
\mathrm{M}-27\end{array}$ & SCZ-32 & 37 & $41.6 \pm 12.3$ & $\begin{array}{l}\mathrm{F}-13 \\
\mathrm{M}-24\end{array}$ & SCZ-37 & Caucasian & AIMS \\
\hline Nithsdale & 51 & $56.2 \pm 15.8$ & $\begin{array}{l}\mathrm{F}-23 \\
\mathrm{M}-28\end{array}$ & SCZ-51 & 49 & $47.9 \pm 13.6$ & $\begin{array}{l}\mathrm{F}-21 \\
\mathrm{M}-28\end{array}$ & SCZ-49 & Caucasian & AIMS \\
\hline $\begin{array}{l}\text { Toronto: } \\
\text { African } \\
\text { American }\end{array}$ & 10 & $35.5 \pm 11.5$ & $\begin{array}{l}\mathrm{F}-3 \\
\mathrm{M}-7\end{array}$ & SCZ-10 & 13 & $30.1 \pm 11.3$ & $\begin{array}{l}\text { F-5 } \\
\text { M-8 }\end{array}$ & SCZ-13 & $\begin{array}{l}\text { African } \\
\text { American }\end{array}$ & AIMS* \\
\hline $\begin{array}{l}\text { Toronto: } \\
\text { Caucasian }\end{array}$ & 30 & $34.9 \pm 8.3$ & $\begin{array}{l}\text { F-11 } \\
\text { M-19 }\end{array}$ & SCZ-30 & 51 & $31.1 \pm 8.8$ & $\begin{array}{l}\mathrm{F}-11 \\
\mathrm{M}-40\end{array}$ & SCZ-51 & Caucasian & AIMS* \\
\hline Vienna & 20 & $37.7 \pm 13.2$ & $\begin{array}{l}\text { F-9 } \\
\text { M-11 }\end{array}$ & $\begin{array}{l}\text { SCZ-11 } \\
\text { SA-5 }\end{array}$ & 41 & $30.8 \pm 10.0$ & $\begin{array}{l}\text { F-18 } \\
\text { M-23 }\end{array}$ & $\begin{array}{l}\text { SCZ-30 } \\
\text { SA-15 }\end{array}$ & Austrian & $\begin{array}{l}\text { TDRS } \\
(\mathrm{n}=38) \\
\text { Clinical } \\
(\mathrm{n}=23)\end{array}$ \\
\hline
\end{tabular}

female (F); male (M); schizoaffective (SA); schizophrenia (SCZ); Tardive Dyskinesia Rating Scale (TDRS).

* Abnormal Involuntary Movement Scale. Converted from modified Hillside Simpson Dyskinesia Scale

${ }^{\dagger}$ Gender of 1 tardive dyskinesia (TD) subject not known

in the original report (Rietschel et al. 2000) because patients with a single evaluation for TD were included here. For Jerusalem, the number of subjects is 113 because 3 subjects were blindly excluded to achieve closer age matching. The Newcastle group consisted of patients recruited in Newcastle, United Kingdom, who were genotyped by the Bergen group (Lovlie et al. 2000). The Nithsdale group consisted of patients recruited in Nithsdale, Scotland, who were also genotyped in Bergen (Steen et al. 1997). The patients from the Toronto center had been recruited in three research clinics in the United States and were genotyped in Toronto. For the current analysis, Caucasian and African American patients were included as separate groups, and the small number of Asian American patients ( $\mathrm{n}=$ 2) was omitted from the analysis. Also, subjects in the Toronto sample who did not have a categorical diagnosis of TD but only AIMS scores were excluded from the current analysis. Table 2 provides a breakdown of the groups by age and gender, according to presence or absence of a categorical diagnosis of TD.

\section{Genotyping}

The ser9gly polymorphism in DRD3 was genotyped in the laboratories of the six participating centers by PCR,
MSC I restriction endonuclease, and electrophoresis, according to the method of Lannfelt et al. (1992). The detailed procedures followed in the Bonn (Rietschel et al. 2000), Bergen (Steen et al. 1997; Lovlie et al. 2000), and Jerusalem centers (Segman et al. 1999) are described in their publications. The same procedures were followed in the Milan and Vienna laboratories.

\section{Statistical Analysis}

For categorical analyses, maximum likelihood chi square statistics were employed. For bivariate comparisons of continuous data, the student $t$-test was used, and for multivariate comparisons, analysis of variance (ANOVA) or covariance (ANCOVA). These analyses were performed with Statistica for Windows 4.5 (Statsoft Inc., 1993) or SPSS 10.0 for Windows (SPSS Inc., 2000). To evaluate the relationship of more than one independent variable to a single binomial-dependent variable, stepwise logistic regression procedures were implemented, as previously described by Lerer et al. (2001). The STATA 6.0 program (Stata Technical Bulletin \# 48 [STB-48] 1999), a general statistical package, was employed for these analyses and also for the metaanalysis described below. Multinomial logistic regression (mlogit) was applied to analyze genotypes, considered as multilevel categorical variables. 
The aim of our analyses was to reevaluate the potential association of TD with the DRD3 gene when the raw data were available through the collaboration of the centers that presented the original reports. The statistical analyses were designed to examine the cumulative predictability of DRD3 as a risk factor for TD while controlling for sources of heterogeneity that could explain conflicting results obtained in the various reports.

First, we performed a meta-analysis estimating and plotting the odds ratios of the contributing centers for TD given the DRD3 risk factor, thus obtaining a statistical estimate of the heterogeneity across centers (groups). Published reports that were not part of the current pooled analysis were included in this metaanalysis. Then, we implemented two sets of analyses on the pooled sample, to possibly explain the degree of heterogeneity. For the first set of analyses, the outcome (response) variables of the logistic regression were DRD3 gly allele carrier status or DRD3 ser-gly genotype. The covariates of the model were the clinical phenotype of interest (i.e., TD present versus absent and the group, given a possible population effect on the frequency of the DRD3 gly allele). In this case, the phenotype of interest is a predictor of outcome and group, a potential confounder. Group was tested by generating a set of dummy variables equal to the number of groups included in the sample in order to evaluate the specific effect of any group. Results from the model are presented as likelihood ratio tests. In a further set of analyses, the outcome variable of the logistic regression was TD phenotype (present or absent), and the covariates of the model were age, gender, and DRD3 gly allele carrier status or DRD3 ser-gly genotype distribution. P values $<.05$ (two tailed) were regarded as significant in all analyses; $p$ values $<0.1$ (two tailed) are given in order to indicate trends, and $\geqslant 0.1$ are listed as NS.

\section{RESULTS}

Initially, we checked for Hardy Weinberg equilibrium (HWE) in each of the index (TD) and comparison (nonTD) groups. All the non-TD groups were in HWE. Among the TD groups, those from Jerusalem $\left(\mathrm{x}^{2}=\right.$ $11.98, p=.0005)$ and Nithsdale $\left(x^{2}=4.42, p=.04\right)$ were not in HWE. We also compared DRD3 gly allele frequency across all the groups. There was a significant difference in allele frequency $\left(x^{2}=46.4, \mathrm{df} 7, \mathrm{p}<.0001\right)$. This was due primarily to the Toronto African American group which had a DRD3 gly allele frequency of 0.80 as compared considerably lower frequencies in the other groups (Bonn: 0.32, Jerusalem: 0.35, Milan: 0.39, Newcastle: 0.38, Nithsdale: 0.31, Toronto Caucasians: 0.35, Vienna: 0.34). Excluding the Toronto African Americans, the difference in DRD3 ser9gly allele frequency among the groups was not significant $\left(x^{2}=4.7\right.$, df $6, p>.1)$.

Table 3 shows a comparison of the frequency of DRD3 alleles between patients with and without TD in each of the groups. There was significant excess of DRD3 gly alleles among the TD patients in the Nithsdale $(\mathrm{p}=.02)$ and Toronto African American $(p=.02)$ groups and a trend in this direction in the Jerusalem group $(p=.09)$. In the Vienna group, the allelic effect was opposite in direction, with a significant excess of ser alleles in patients with $\operatorname{TD}(p=.02)$.

Table 3 also shows DRD3 ser-gly genotypes in the TD and non-TD patients of each group. Comparison of

Table 3. Allele and genotype frequencies in the individual groups

\begin{tabular}{|c|c|c|c|c|c|c|c|c|c|}
\hline \multirow[b]{2}{*}{ Group } & \multirow{2}{*}{$\begin{array}{c}\text { TD } \\
\text { Status }\end{array}$} & \multirow{2}{*}{$\begin{array}{l}\text { No. } \\
\text { Patients }\end{array}$} & \multicolumn{2}{|c|}{$\begin{array}{c}\text { Allele } \\
\text { Frequency }\end{array}$} & \multicolumn{2}{|c|}{ Significance } & \multicolumn{2}{|c|}{$\begin{array}{l}\text { Genotype } \\
\text { Frequency }\end{array}$} & \multirow{2}{*}{$\frac{\text { Significance }}{\left(\operatorname{LR} x^{2}, \text { df } 1\right)}$} \\
\hline & & & ser & gly & $\left(\mathrm{ML} \mathrm{x}^{2}, \mathrm{df} \mathbf{1}\right)$ & ser-ser & ser-gly & gly-gly & \\
\hline \multirow[t]{2}{*}{ Bonn } & TD-Y & 85 & 0.66 & 0.34 & NS & 0.44 & 0.46 & 0.11 & NS \\
\hline & TD-N & 155 & 0.69 & 0.31 & & 0.47 & 0.44 & 0.90 & \\
\hline \multirow[t]{2}{*}{ Jerusalem } & TD-Y & 55 & 0.59 & 0.41 & $x^{2}=2.8$ & 0.24 & 0.71 & 0.55 & $x^{2}=15.9$ \\
\hline & TD-N & 58 & 0.70 & 0.30 & $p=.09$ & 0.48 & 0.43 & 0.86 & $p=.0004$ \\
\hline \multirow[t]{2}{*}{ Milan } & TD-Y & 34 & 0.60 & 0.40 & NS & 0.38 & 0.44 & 0.18 & NS \\
\hline & TD-N & 59 & 0.62 & 0.38 & & 0.34 & 0.56 & 0.10 & \\
\hline \multirow[t]{2}{*}{ Newcastle } & TD-Y & 32 & 0.56 & 0.44 & NS & 0.34 & 0.44 & 0.22 & NS \\
\hline & TD-N & 37 & 0.68 & 0.32 & & 0.46 & 0.43 & 0.11 & \\
\hline \multirow[t]{2}{*}{ Nithsdale } & TD-Y & 51 & 0.62 & 0.38 & $x^{2}=5.3$ & 0.45 & 0.33 & 0.22 & $x^{2}=9.5$ \\
\hline & TD-N & 49 & 0.77 & 0.23 & $p=.02$ & 0.57 & 0.39 & 0.04 & $p=.009$ \\
\hline \multirow{2}{*}{$\begin{array}{l}\text { Toronto: } \\
\text { African American }\end{array}$} & TD-Y & 10 & 0.50 & 0.95 & $x^{2}=5.4$ & - & 0.10 & 0.90 & $-^{*}$ \\
\hline & TD-N & 13 & 0.31 & 0.69 & $p=.02$ & - & 0.62 & 0.38 & \\
\hline \multirow{2}{*}{$\begin{array}{l}\text { Toronto: } \\
\text { Caucasian }\end{array}$} & TD-Y & 30 & 0.63 & 0.37 & NS & 0.43 & 0.40 & 0.17 & NS \\
\hline & TD-N & 51 & 0.66 & 0.34 & & 0.37 & 0.57 & 0.06 & \\
\hline \multirow[t]{2}{*}{ Vienna } & TD-Y & 20 & 0.80 & 0.20 & $x^{2}=5.2$ & 0.70 & 0.20 & 0.10 & $x^{2}=7.6$ \\
\hline & TD-N & 41 & 0.60 & 0.40 & $p=.02$ & 0.41 & 0.37 & 0.22 & $p=.02$ \\
\hline
\end{tabular}

* Significance could not be computed because of absence of ser-ser homozygotes.

$\mathrm{NS}=$ not significant $(p \geq 0.1)$. 
genotype frequency was by the subroutine "genhwcci" as implemented in STATA 6.0 (Stata Technical Bulletin \# 48 [STB-48] 1999). The program estimates allele frequency, genotype frequencies, and disequilibrium coefficients for co-dominant traits or data of completely known genotypes in case-control studies. It performs asymptotic Hardy-Weinberg equilibrium test for both cases and controls in case-control studies. It also tests the Hardy-Weinberg equilibrium for genotypic counts of cases, under the assumption that the genotypic counts of controls are under Hardy-Weinberg equilibrium. This test showed a significant difference in the Jerusalem group $\left(x^{2}=15.85, p=.0004\right)$, caused by an excess of ser-gly heterozygotes among the TD patients. The genotypes of the Nithsdale TD patients were significantly different from those of the non-TD patients in this group $(p=.009)$ because of an excess of gly-gly homozygotes. As there were no ser-ser homozygotes among the Toronto African American patients, the test could not be performed for this group. A simple chi square test, however, showed a significant excess of gly-gly homozygotes among the African American TD patients $(p=.008)$. In the Vienna group, genotype frequencies were also significantly different between TD and non-TD patients $\left(\mathrm{x}^{2}=7.61, \mathrm{df}=2, \mathrm{p}=.02\right)$, but in this case, there was an excess of ser-ser homozygotes among the TD patients.

Figure 1 shows the results of the meta-analysis and presents observed distribution of odds ratios for TD given DRD3 gly presence in seven of the groups included in the pooled analysis (Toronto African Americans excluded), as well as in three additional published reports. The Mantel-Haenszel $(\mathrm{M}-\mathrm{H})$ pooled odds ratio across all the available data is 1.33 (95\% CI 1.04-1.70), pointing to a small but significant effect of DRD3gly as risk factor for TD. The cumulative pooled estimate (Lau et al. 1992) shows a cumulative odds ratio of 1.52 (95\% CI 1.08-1.68), corresponding to a $p$-value $<.0001$, suggesting a much stronger effect of DRD3 gly as a risk factor. It is important, however, to note the degree of heterogeneity $\left(x^{2}=16.97, \mathrm{df}=9, p=.05\right)$, with odds ratios ranging from 0.3 for the Vienna groups to 3.53 for Liao et al. (2001). Therefore, a major goal was to disentangle the origin of the heterogeneity and to re-evaluate TD/ DRD3gly association while controlling for potential confounders. These are: 1) differences among groups in DRD3 ser-gly allele frequency; 2) possible group differences in the evaluation of TD; and 3) the impact of age and gender, both known to be susceptibility factors for TD. Therefore, we implemented a series of stepwise logistic regression procedures.

In the first set of analyses, the response variable was DRD3 gly allele carrier status (ser-gly heterozygotes and gly-gly homozygotes defined as gly allele carriers). With stepwise logistic regression analysis, we evaluated the effect of group and TD status as predictors of the response variable. The likelihood ratio (LR) test of the two models (group + TD status and group alone) determines the significance of TD status controlled for the potential confounding effect of group. The results of this analysis are shown in Table 4A. The LR test for TD status predicting DRD3 gly allele carrier status was significant $\left(\mathrm{x}^{2}=4.46\right.$, df $\left.1, p=.04\right)$. The combined analysis of genotypes was conducted according to the same approach. A multinomial logistic regression with the dependent variable being DRD3 genotype (3 levels) showed a significant LR test for TD status $\left(x^{2}=6.62, \mathrm{df}\right.$ $2, p=.04$ ), while controlling for the possible confounding effects of populations, as shown in Table 4B.

In the second set of logistic regressions, the response variable was TD status and the predictors evaluated were age, gender, and DRD3 gly allele carrier status (Table 5A). There were significant effects of age $(p<$ $.0001)$, gender $(p=.005)$, and DRD3 gly allele $(p=.04)$ on TD status. The net effect of DRD3 allele (i.e., the LR test for DRD3 allele was again significant: $\mathrm{x}^{2}=5.02, \mathrm{df} 1$, $p=.02$ ). Multinomial logistic regressions on DRD3 ser9gly genotype are shown in Table 5B. There were significant effects of age $(p<.0001)$, gender $(p=.04)$, and DRD3 genotype ( $p=.01)$ on TD status. The LR test for DRD3 genotype was significant $\left(\mathrm{x}^{2}=7.51\right.$, $\mathrm{df} 1, p=$ .002). We conducted further subsidiary analyses in order to identify the most appropriate genotypic model. A co-dominant (additive) model yielded $x^{2}=4.46, \mathrm{df} 1$, $p=.3$. A dominant model was not significant $\left(x^{2}=1.44\right.$, df $1, p=.2)$, whereas a recessive model was the strongest $\left(x^{2}=6.3, p=.01\right)$.

In addition to classifying TD status in a dichotomous fashion, we performed analyses of the relationship of DRD3 genotype to abnormal involuntary movement as a continuous variable rated by the AIMS. Six groups had AIMS ratings (Bonn, Jerusalem, Newcastle, Nithsdale, Toronto African-Americans,s and Toronto Caucasians) and were included in the analyses. In ANCOVA analyses, AIMS total score was the dependent variable; group, gender, and DRD3 allele carrier status were the independent variables, and age was a covariate. There were significant main effects of group $(\mathrm{F}=6.01$, df $5, p<$ $.0001)$, DRD3 allele $(\mathrm{F}=4.2 \mathrm{df} 1, p=.04)$, and covariate age $(\mathrm{F}=56.0$, df $1, p<.0001)$, and a significant interaction between group and DRD3 allele $(\mathrm{F}=5.4, \mathrm{df} 5, p<$ .0001). The same elements were included in a second ANCOVA, except that DRD3 genotype was substituted for DRD3 allele. In this model, the effect of group was significant $(\mathrm{F}=5.8, \mathrm{df} 5, p<.0001)$ and of the covariate age $(\mathrm{F}=53.8$, df $1, p<.0001)$. Whereas the main effect of DRD3 genotype was not significant $(\mathrm{F}=2.8$, df $2, p=$ .06), the interaction between group and DRD3 genotype was $(\mathrm{F}=3.7$, df $9, p<.0001)$. Post hoc comparison with a contrast test of adjusted mean AIMS total scores (Figure 2) showed significantly higher scores for the gly-gly versus ser-ser $(p<.0001)$ and ser-gly $(p=.006)$ genotypes. 


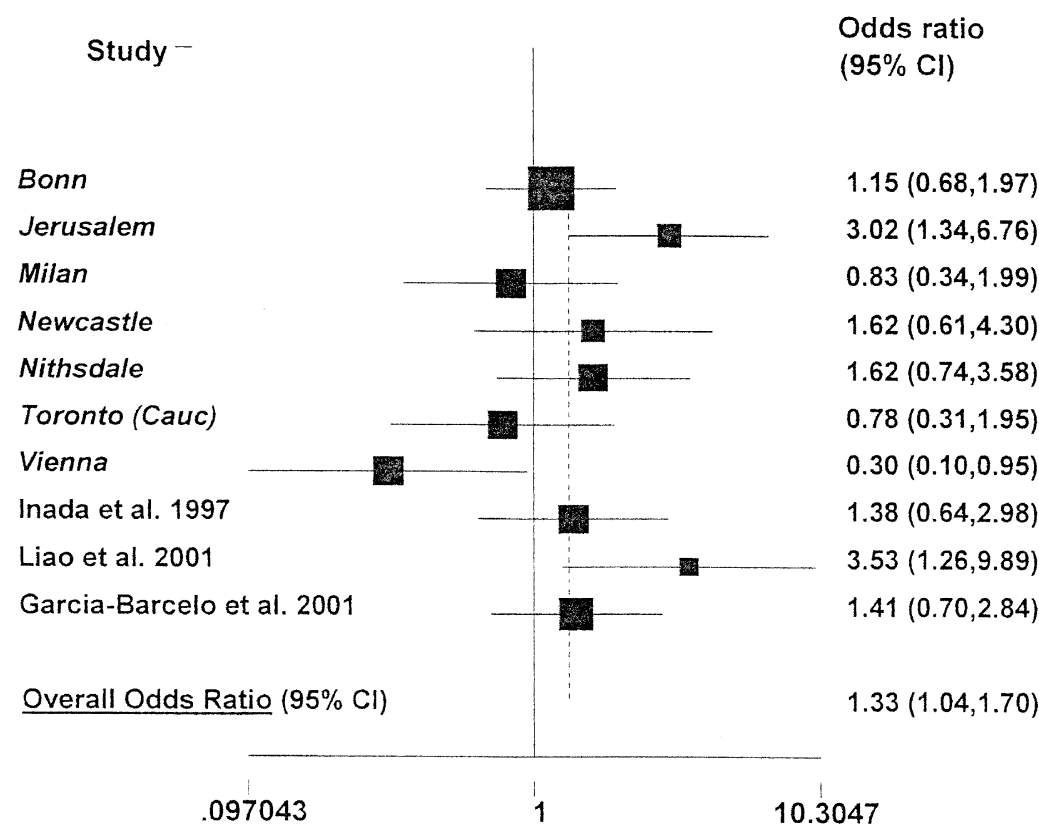

$\%$ Weight

23.3

6.4

10.0

5.9

8.9

9.5

10.1

10.1

3.7

12.1

Figure 1. Distribution of odds ratios for TD given DRD3 risk allele (gly) among 7 of the groups included in the current combined analysis and three other published studies. The size of each plot is proportional to the sample size of each group. The Mantel-Haenszel pooled OR is = 1.33 (95\% CI 1.04-1.70) and the associated test of OR $=$ is significant $\left(\chi^{2}=5.12\right.$, df.1, $\mathrm{p}=$ .02), while the cumulative pooled OR (Lau et al, 1992) is 1.52 with $\mathrm{z}=11.78$ and $\mathrm{p}<$ .001. The heterogeneity $\chi^{2}=$ 16.97 , df $9, \mathrm{p}=0.49$.

\section{DISCUSSION}

Pharmacogenetics addresses the role of genetic factors in accounting for variability among individuals in response to medication and susceptibility to adverse effects. Casecontrol association designs are a powerful method for generating data of this type. Family based designs, though potentially advantageous in reducing spurious effects of population stratification, are difficult to implement in the pharmacogenetic context. In fact, it is highly unlikely that family based samples of sufficient power can be recruited while controlling for both diagnostic

Table 4A. Logistic regression for variables predicting DRD3gly allele carrier status in patients with and without TD from the 8 groups.

\begin{tabular}{|c|c|c|c|c|}
\hline Variable & Log Likelihood & Chi Square (df) & Significance & Odds Ratio \\
\hline Null Model & -1019.8927 & - & - & - \\
\hline Model A & -990.16283 & $49.43(8)$ & & \\
\hline \multicolumn{5}{|l|}{ Center } \\
\hline Bonn & & & & 0.92 \\
\hline Jerusalem & & & & 1.04 \\
\hline Milan & & & & 1.23 \\
\hline Newcastle & & & & 1.10 \\
\hline Nithsdale & & & & 0.85 \\
\hline Toronto AA & & & & 7.96 \\
\hline Toronto Cauc & & & & 1.06 \\
\hline Vienna* & & & & - \\
\hline TD Status & & & & 1.26 \\
\hline \multicolumn{5}{|l|}{ Model B } \\
\hline Center & -992.39356 & $44.97(7)$ & & \\
\hline Bonn & & & & 0.92 \\
\hline Jerusalem & & & & 1.08 \\
\hline Milan & & & & 1.24 \\
\hline Newcastle & & & & 1.19 \\
\hline Nithsdale & & & & 0.89 \\
\hline Toronto AA & & & & 8.12 \\
\hline Toronto Cauc & & & & 1.07 \\
\hline Vienna* $^{*}$ & & & & - \\
\hline \multicolumn{5}{|l|}{ LRtest } \\
\hline (-2[(LogL model B- & & & & \\
\hline (LogL model A)] & - & $4.46(1)$ & 0.034 & - \\
\hline
\end{tabular}

*Dropped due to colinearity; likelihood ratio (LR); tardive dyskinesia (TD). 
Table 4B. Multinomial logistic regression for variables predicting DRD3 genotypes in patients with and without TD from the 8 groups

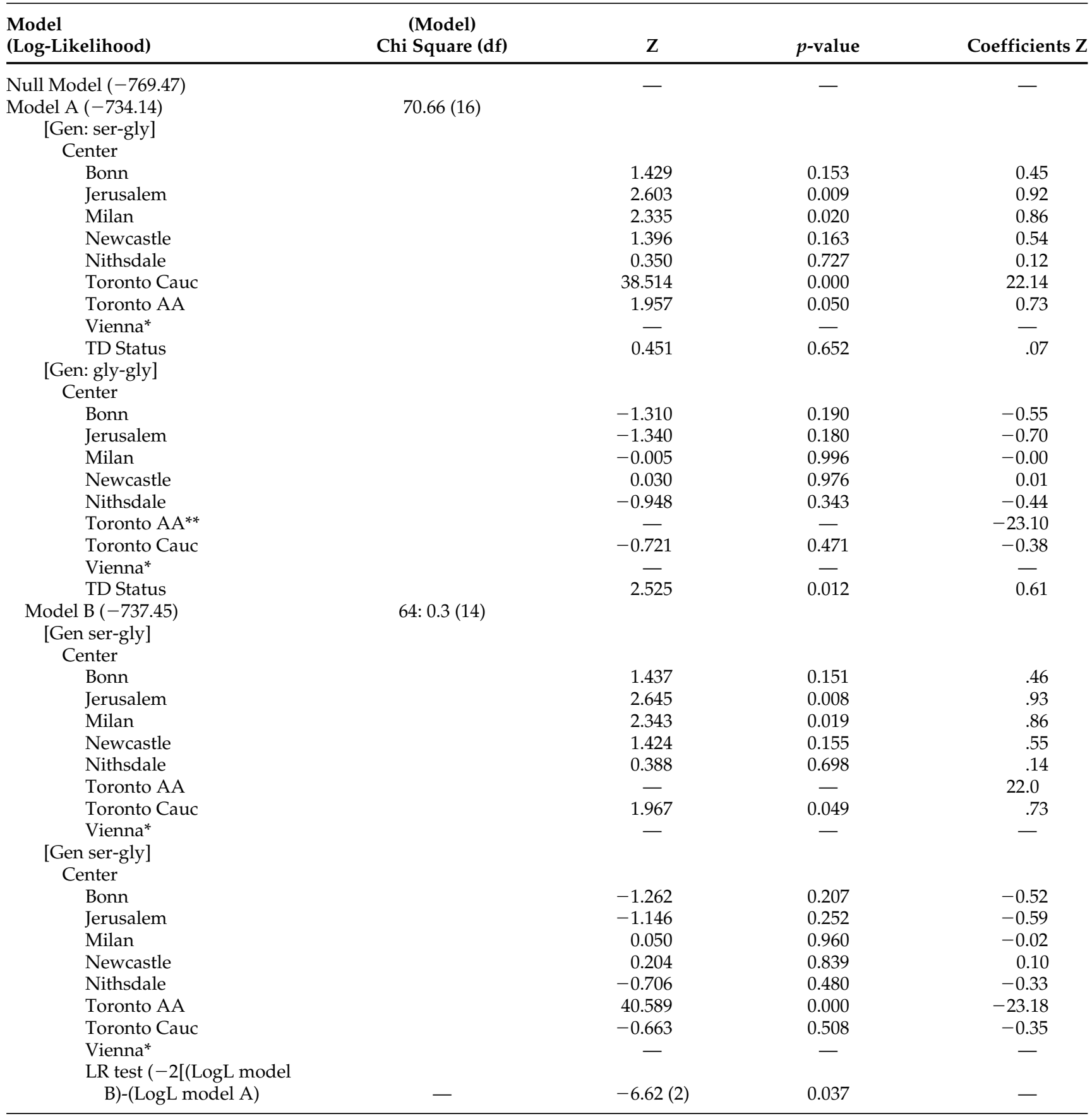

Likelihood ratio (LR); Tardine dyskinesia (TD).

* Dropped due to colinearly.

** There are no non-TD subjects with gly-gly genotypes in the Toronto African American sample.

and drug exposure elements of the phenotype. Case control designs are not immune to power consideration, as gene effects are likely to be small and interactions among genes will need to be studied, both requiring large samples. Therefore, there is frequently a need to pool samples from different centers and even from different pop- ulations. Though increasing power, this can lead to spurious results if allele frequencies for the genes being studied vary among the populations. On the other hand, there is a distinct advantage to studying pharmacogenetic issues across populations, so it can be determined to what extent findings are generally applicable. 
Table 5. Logistic Regression Analysis for Variables Predicting Tardive Dyskinesia Phenotype in Patients from the 8 Groups

\begin{tabular}{|c|c|c|c|c|c|c|}
\hline \multicolumn{7}{|c|}{ A. Allelic Effect } \\
\hline Null Model & \multicolumn{3}{|c|}{$\log L=.1081 .06$} & \multirow{3}{*}{$\begin{array}{c}\text { LR } \text { chi }^{2}= \\
\frac{\text { LR } \text { chi }^{2}(3 \mathrm{df}=96.4)}{\text { [95\% Conf. Interval] }}\end{array}$} & \multirow[b]{3}{*}{$\mathbf{Z}$} & \multirow{3}{*}{$\begin{array}{c}p \\
p<.0001 \\
p>|\mathrm{z}|\end{array}$} \\
\hline \multirow[t]{3}{*}{ Model A } & \multicolumn{3}{|c|}{$\log \mathrm{L}=.1003 .82$} & & & \\
\hline & Variables & Odds Ratio & Std. Error & & & \\
\hline & $\begin{array}{l}\text { Age } \\
\text { Sex } \\
\text { DRD3gly } \\
\text { Allele }\end{array}$ & $\begin{array}{l}1.03 \\
1.40 \\
1.28\end{array}$ & $\begin{array}{l}.004 \\
.154 \\
.142\end{array}$ & $\begin{array}{l}1.03-1.04 \\
1.13-1.74 \\
1.03-1.59\end{array}$ & $\begin{array}{l}9.161 \\
3.101 \\
2.243\end{array}$ & $\begin{array}{l}0.000 \\
0.002 \\
0.025\end{array}$ \\
\hline \multirow[t]{3}{*}{ Model B } & \multicolumn{2}{|c|}{$\log L=-1.006 .33-$} & & \multicolumn{2}{|l|}{$\underline{L} \operatorname{chi}^{2}(2 \mathrm{df})=91.4$} & $\mathrm{p}<.001$ \\
\hline & Variables & Odds Ratio & Std. Error & [95\% Conf. Interval] & $\mathbf{Z}$ & $p<|\mathbf{z}|$ \\
\hline & $\begin{array}{l}\text { Age } \\
\text { Sex } \\
\text { Lrtest } \\
(-2[\operatorname{LogL~Mod}\end{array}$ & $\begin{array}{c}1.03 \\
1.40 \\
\text { ogL Model A) }\end{array}$ & $\begin{array}{l}.004 \\
.150\end{array}$ & $\begin{array}{c}1.02-1.04 \\
1.13-1.73 \\
\text { LR } \text { chi }^{2}=5.02\end{array}$ & $\begin{array}{l}9.138 \\
3.092\end{array}$ & $\begin{array}{c}0.00 \\
0.02 \\
p=.02\end{array}$ \\
\hline \multicolumn{7}{|c|}{ B. Genotypic Effect } \\
\hline Null Model & \multicolumn{2}{|c|}{$\log L=-499.41$} & & LR chi $^{2}$ & & $p$ \\
\hline \multirow[t]{3}{*}{ Model A } & \multicolumn{2}{|c|}{$\log L=-499.41$} & & $L R \operatorname{chi}^{2}(3 \mathrm{df})=53.1$ & & $\underline{\mathrm{p}<.0001}$ \\
\hline & Variables & Odds Ratio & Std. Error & [95\% Conf. Interval] & $\mathbf{Z}$ & $p>|\mathbf{z}|$ \\
\hline & $\begin{array}{l}\text { Age } \\
\text { Sex } \\
\text { DRD3 } \\
\text { genotypes }\end{array}$ & $\begin{array}{l}1.03 \\
1.41 \\
1.06\end{array}$ & $\begin{array}{l}.005 \\
.220 \\
.022\end{array}$ & $\begin{array}{l}1.03-1.05 \\
1.04-1.92 \\
1.01-1.10\end{array}$ & $\begin{array}{l}6.53 \\
2.23 \\
2.73\end{array}$ & $\begin{array}{l}0.000 \\
0.025 \\
0.006\end{array}$ \\
\hline \multirow[t]{3}{*}{ Model B } & \multicolumn{2}{|c|}{$\log L=-503.16$} & & $\operatorname{LR} \operatorname{chi}^{2}(2 \mathrm{df})=45.7$ & & $p<.0001$ \\
\hline & Variables & Odds Ratio & Std. Error & [95\% Conf. Interval] & $\mathbf{Z}$ & $\mathbf{p}>|\mathbf{z}|$ \\
\hline & $\begin{array}{l}\text { Age } \\
\text { Sex } \\
\text { Lrtst } \\
(-2[\operatorname{LogL} \text { Mod }\end{array}$ & $\begin{array}{c}1.03 \\
1.40 \\
\text { ogL Model A)] }\end{array}$ & $\begin{array}{l}.005 \\
.217\end{array}$ & $\begin{array}{c}1.02-1.04 \\
1.03-1.91 \\
\left.\operatorname{LR} \operatorname{ch}^{2}(1 \mathrm{df})=7.51\right)\end{array}$ & $\begin{array}{l}6.46 \\
2.18\end{array}$ & $\begin{array}{c}0.000 \\
0.029 \\
p=.006\end{array}$ \\
\hline
\end{tabular}

Because it is important to be able to conduct largescale pharmacogenetic studies in a case control context, appropriate approaches for dealing with potential confounders such as population effects need to be developed. Though it is obviously best to use ethnically homogeneous samples, this is not always possible. One method of ruling out population influences on the markers being studied is to type additional markers that are putatively unrelated to the phenotype and to determine the degree of stratification present in the sample (Pritchard and Rosenberg 1999). When samples from different populations are pooled, it is essential to take population effects into account. A further consideration is that demographic factors such as age and gender, as well as other variables, can influence the phenotype and need to be considered in the analyses.
In the current analysis, we applied a statistical approach, stepwise logistic regression, in order to evaluate the relationship between susceptibility to TD and a serine to glycine polymorphism in the dopamine D3 receptor gene, in eight groups of patients recruited from different populations. The approach allowed us to account for potentially confounding effects of the origin of the patients, and also for other variables such as age and gender that can influence the phenotype. Previously, Lerer et al. (2001) applied this approach to an analysis of the 5-HT2C receptor gene in 513 patients with recurrent major depression (MDD), 649 patients with bipolar disorder (BPD), and 901 normal controls from 9 European countries. We were able to demonstrate significant association of a cys23ser polymorphism in the 5-HT2C receptor gene with MDD and 


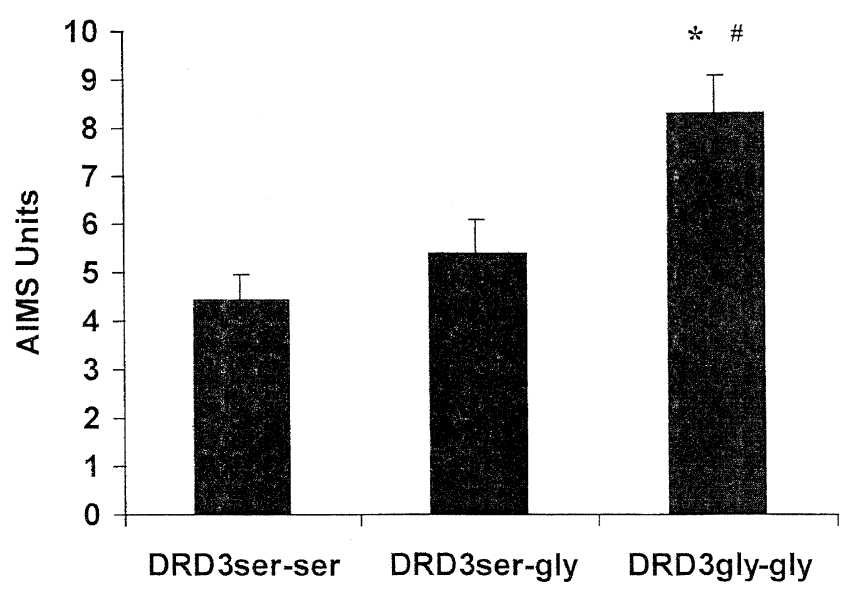

Figure 2. Adjusted mean AIMS scores (bars represent standard error) derived from ANCOVA with age as covariates of patients from 6 groups (Bonn, Jerusalem, Newcastle, Nithsdale, Toronto African Americans, Toronto Caucasians) according to DRD3 ser9gly genotype. *vs. ser-ser, $\mathrm{p}<.0001$; \#versus ser-gly, $\mathrm{p}<.006$.

BPD, in spite of substantial variability in allele frequency among the different populations (considerably greater than that observed for DRD3 ser9 gly in the current study).

In terms of the genes examined, there are two distinct approaches to the design of pharmacogenetic studies. The first employs a classic candidate gene approach and examines genes that have an a priori potential relationship to the phenotype under study. The second approach is atheoretical and involves scanning large numbers of SNPs in order to identify loci associated with the phenotype. Ultimately, whole genome scanning by this method is anticipated (Risch, 2000), although there is considerable debate as to the theoretical underpinnings of the approach (Weiss and Terwilliger 2000) and there are still practical and financial impediments to its application. The present analysis involved data collected on the basis of a candidate gene approach and examined one SNP in a single gene. It demonstrates the small contribution of a single gene to vulnerability to TD and also indicates that this contribution is variable among populations. It is likely, however, that multiple genes contribute to susceptibility to TD, as is anticipated for pharmacogenetic traits in general (Roses 2000).

The results reported here must be considered in the context of significant limitations. From the phenotypic standpoint, evaluations of TD were conducted by a number of different clinicians in different centers. Although inter-rater reliability was achieved within centers, this was not the case between centers. Moreover, different rating scales were used to rate abnormal involuntary movements as a basis for applying the RDC-TD. These limitations are inevitable in a post hoc analysis of data collected in different centers. Nevertheless, there was standardization in applying the RDC-TD, and five of the eight patient groups were rated with the AIMS. Also, the inclusion of group as a confounding variable in the logistic regression controls for this problem to a certain extent. It should also be noted that genotyping was done in different laboratories. But methods are quite standard, and the margin of error reasonably small.

Overall, the results of this analysis support a contribution of the DRD3 ser9 gly polymorphism to TD susceptibility. The likelihood that patients who carry the gly variant of the gene will manifest TD is increased to a small yet significant degree over those who do not. This conclusion is supported by the results of the metaanalysis, which included the studies that were part of the pooled analysis as well as three additional published studies. It demonstrated a pooled odds ratio of 1.33 and a cumulative odds ratio of 1.52 . The conclusion is strengthened by the results of the logistic regression analyses that demonstrated a significant effect of the DRD3 ser9 gly polymorphism over and above the significant contributions of group, age, and gender. Other than preliminary suggestions from in vitro studies regarding an effect of the ser9gly variant on receptor binding (Lundstrom and Turpin 1996), the mechanism whereby DRD3 might be implicated in susceptibility to TD remains unclear and should be studied further in appropriate in vivo models. Besides DRD3, other genes that have been associated with TD include the 5-HT2C receptor gene (HTR2C) (Segman et al. 2000), the 5HT2A (HTR2A) receptor gene (Segman et al. 2001), cytochrome P450 1A2 (CYP1A2) (Basile et al. 2000), and manganese superoxide dismutase (Hori et al. 2000). These findings have still to be supported by other groups, one replication (Tan et al. 2001) and one nonreplication (Basile et al., 2001) having been published for HTR2A, and one non-replication for CYP1A2 (Schulze et al. 2001). It is likely that other associations will be observed and, if replicated, elucidate a polygenic background to TD.

For complex phenotypes such as response to psychotropic drugs and susceptibility to adverse effects (of which TD is an illustrative example), it is likely that several genes will be implicated, each individual gene contributing only a relatively small risk increment. A major challenge for pharmacogenetics is how to conceptualize and best detect the presence or absence of synergistic effects of genes (Phillips 1998; Cordell et al. 2001). These effects are likely to be additive or interactive (epistatic). If the combined effect of two or more genes is greater than the simple sum of the effects of each single gene, then the gene-gene interaction points to an epistatic rather than an additive effect. In a simple formulation, we are interested in seeing whether the observed phenotype is better predicted by a combination of risk genotypes at different loci when they are 
jointly present in the same subject rather than when they act independently, as in those subjects where only one of the risk genotypes is present. In this way, the test of a statistical genetic interaction is similar to the concept of epistasis proposed by Fisher (1918). In the context of TD, Segman et al. (2000) demonstrated an additive contribution of DDRD3 and HTR2C to the severity of abnormal involuntary movements (AIMS scores) in schizophrenia patients without evidence for an interaction. Interactions between loci may be within a single gene, as demonstrated for the effect of complex haplotypes of SNPs in the coding region and promoter of the $\beta-2$ adrenergic receptor gene on the bronchodilator response to asthma therapy (Drysdale et al. 2000). Interactions may be between loci in different genes as recently observed in a study of genetic susceptibility to breast cancer (Ritchie et al. 2001). In the case of TD, Segman et al. (2002) have demonstrated an interaction between the cytochrome P450 $17 \alpha$-hydroxylase gene (CYP-17) and DRD3, an effect of CYP-17 on AIMS scores being demonstrable only in patients homozygous for the gly allele of DRD3.

These considerations indicate that definitive studies on the pharmacogenetics of TD will require large samples. Prospective designs that employ standardized evaluation instruments will reduce heterogeneity among centers in the characterization of the phenotype, enhancing the likelihood of consistent results. As has been demonstrated for DRD3, smaller studies can identify positive findings that are subsequently replicated in larger samples. Given the likely small contribution of each gene to susceptibility, however, the potential for type II error is substantial. Certainly, the analysis of interactive effects among several genes will not be possible in small samples, although novel methods of analysis can permit the use of smaller samples than had previously been anticipated (Ritchie et al. 2001). These considerations are generally applicable to the field of pharmacogenetics, and to the pharmacogenetics of psychotropic drugs in particular. In the context of such large, multicenter samples, application of statistical techniques such as those used in the present study, will allow gene effects to be demonstrated over and above the confounding influence of population, demographics, and other confounding variables.

\section{ACKNOWLEDGMENTS}

The following contributed to the projects of the participating centers: Harald Krauss, Tilo Held (Bonn); Tom MacEwan (Dumfries); Boris Finkel, Michael Schlaffman, Avi Yakir (Jerusalem); Richard Blennerhassett (Newcastle); Jeffrey A. Lieberman, Steven G. Potkin (Toronto); Karoline Fuchs, Thomas Kapitany, Christian Gebhardt, Angela Heiden (Vienna).

This work was supported by grants from Hadassit Medical Research Corporation, Hadassah Medical Center (to RHS and
BL); the Hochschuljubiläumsstiftung der Stadt Wien, 1992 (to HNA); the Dr. Einar Martens Fund and the Research Council of Norway (to RL and VMS); and a NARSAD 2000 Investigator Initiated Award (to FM).

\section{REFERENCES}

Andreassen OA, MacEwan T, Gulbrandsen AK, McCreadie RG, Steen VM (1997): Non-functional CYP2D6 alleles and risk for neuroleptic-induced movement disorders in schizophrenic patients. Psychopharmacology (Berl) 131(2):174-179

Armstrong M, Daly AK, Blennerhassett R, Ferrier N, Idle JR (1997): Antipsychotic drug-induced movement disorders in schizophrenics in relation to CYP2D6 genotype. Br J Psychiatry 170:23-26

Arranz MJ, Munro J, Sham P (1998): Meta-analysis of studies on genetic variation in 5-HT2A receptors and clozapine response. Schiz Res 32:93-99

Arthur H, Dahl ML, Siwers B, Sjoqvist F (1995): Polymorphic drug metabolism in schizophrenic patients with tardive dyskinesia. J Clin Psychopharmacol 15:211-216

Basile VS, Masellis M, Badri F, Paterson AD, Meltzer HY, Lieberman JA, Potkin SG, Macciardi F, Kennedy JL (1999): Association of the MscI polymorphism of the dopamine D3 receptor gene with tardive dyskinesia in schizophrenia. Neuropsychopharmacology 21:17-27

Basile VS, Ozdemir V, Masellis M, Walker ML, Meltzer HY, Lieberman JA, Potkin SG, Alva G, Kalow W, Macciardi FM, Kennedy JL (2000): A functional polymorphism of the cytochrome P450 1A2 (CYP1A2) gene: association with tardive dyskinesia in schizophrenia. Mol Psychiatry 4:410-417

Basile VS, Ozdemir V, Masellis M, Meltzer HY, Lieberman JA, Potkin SG, Macciardi FM, Petronis A, Kennedy JL (2001): Lack of association between serotonin-2A receptor gene (HTR2A) polymorphisms and tardive dyskinesia in schizophrenia. Mol Psychiatry 6:230-234

Brown KW, White T (1991): HLA and TD. Br J Psychiatry 158:270-272

Canoso RT, Romero JA, Yunis EJ (1986): Immunogenetic markers in chlorpromazine induced TD. J Neuroimmunol 12:247-252

Catalano M (1999): Psychiatric genetics '99: The challenges of psychopharmacogenetics. Am J Hum Genet 65:606610

Cavallaro R, Regazzetti MG, Mundo E, Brancato V, Smeraldi E (1993): Tardive dyskinesia outcomes: clinical and pharmacological correlates of remission and persistence. Neuropsychopharmacology 8(3):233-239

Chen CH, Wei FC, Koong FJ, Hsiao KJ (1997): Association of TaqI A polymorphism of dopamine D2 receptor gene and tardive dyskinesia in schizophrenia. Biol Psychiatry 41(7):827-829

Chong SA, Tan EC, Tan CH, Mahendren R, Tay AHN, Chua HC (2000): Tardive dyskinesia is not associated with the serotonin gene polymorphism (5-HTTLPR) in Chinese. Am J Med Genet 96:712-715

Cichon S, Nothen MM, Rietschel M, Propping P (2000): Pharmacogenetics of schizophrenia. Am J Med Genet 97:98-106 
Cordell HJ, Todd JA, Hill NJ, Lord CJ, Lyons PA, Peterson LB, Wicker LS, Clayton DG (2001): Statistical modeling of interlocus interactions in a complex disease: rejection of the multiplicative model of epistasis in type I diabetes. Genetics 158:357-367

Drysdale CM, McGraw DW, Stack CB, Stephens JC, Judson RS, Nandabalan K, Arnold K, Ruano G, Liggett SB (2000): Complex promoter and coding region b2-adrenergic receptor haplotypes alter receptor expression and predict in vivo responsiveness. Proceedings of the National Academy of Science USA 97:10483-10488

Emsley RA, Oosthuizen PP, Toubert AF, Hawkridge SM, Stein DJ (1999): Treatment of schizophrenia in lowincome countries. Int J Neuropsychopharmacol 2:321-325

Fisher RA (1918): The correlation between relatives on the supposition of Mendelian inheritance. Trans. R. Soc. Edin. 52:399-433

Garcia-Barceló MM, Lam LCW, Ungvari GS, Lam VKL, Tang WK (2001): Dopamine D3 receptor gene and tardive dyskinesia in Chinese schizophrenic patients. J Neural Transm 108:671-677

Guy W (1976): ECDEU Assessment Manual for Psychopharmacology; Revised edition. Washington DC, Department of Health, Education and Welfare

Hori H, Ohmori O, Shinkai T, Kojima H, Okano C, Suzuki T, Nakamura J (2000): Manganese superoxide dismutase dene polymorphism and schizophrenia: relation to tardive dyskinesia. Neuropsychopharmacology 23:170177

Inada T, Dobashi I. Sugita T, Inagaki A, Kitao Y, Matsuda G, Kato S, Takano T, Yagi G, Asai M (1997): Search for a susceptibility locus to tardive dyskinesia. Human Psychopharmacology 12:35-39

Jeste DV, Caligiuri MP, Paulsen JS, Heaton RK, Lacro JP, Harris MJ, Bailey A, Fell RL, McAdams LA (1995): Risk of tardive dyskinesia in older patients. Arch Gen Psychiatry 52:756-765

Jeste DV, Wyatt RJ (1982): Understanding and Treating Tardive Dyskinesia. New York, Guilford Press

Kane JM, Jeste DV, Barnes TRE, Casey DE, Cole JO, Davis JM, Gualtieri CT, Schooler NR, Sprague RL, Wetterstein RM (1992): Tardive Dyskinesia: A Task Force Report of the American Psychiatric Association. Washington DC, American Psychiatric Association

Kane JM, Smith JM (1982): Tardive dyskinesia: prevalence and risk factors, 1959 to 1979. Arch Gen Psychiatry 37: 473-481

Kane JM (1995): Tardive dyskinesia: Epidemiological and clinical presentation. In: Bloom FE, Kupfer DJ (eds), Psychopharmacology: The 4th Generation of Progress. New York, Raven Press

Kapitany T, Meszaros K, Lenzinger E, Schindler SD, Barnas C, Fuchs K, Sieghart W, Aschauer HN, Kasper S (1998): Genetic polymorphisms for drug metabolism (CYP2D6) and tardive dyskinesia in schizophrenia. Schizophr Res 32:101-106

Krawezak M, Reiss J, Cooper DN (1992): The mutational spectrum of single base-pair substitutions in mRNA splice junctions of human genes: causes and consequences. Hum Genet 90:41-54

Lannfelt L, Sokoloff P, Martres MP, Pilon C, Giros B, Jonsson
E, Sedvall G, Schwartz JC (1992): Amino acid substitution in the dopamine $\mathrm{D}_{3}$ receptor as a useful polymorphism for investigating psychiatric disorders. Psychiatric Gen 2:249-256

Lau J, Antman EM, Jimenez-Silva J, Kupelnick B, Mosteller F, Chalmers TC (1992): Cumulative meta-analysis of therapeutic trials for myocardial infarction. $\mathrm{N}$ Eng J Med 327:248-254

Le Coniat M, Sokoloff P, Hillion J, Martres MP, Giros B, Pilon C, Schwartz JC, Berger R (1991): Chromosomal localization of the human dopamine $\mathrm{D}_{3}$ receptor gene. Hum Genet 87:618-620

Lerer B (ed): Pharmacogenetics of Psychotropic Drugs. Cambridge, Cambridge University Press (in press)

Lerer B, Macciardi F. (in press): Pharmacogenetics of antidepressant and mood stabilising drugs: A review of candidate gene studies and future research directions. International Journal of Neuropsychopharmacology

Lerer B, Macciardi F, Segman RH, Adolfsson R, Blackwood D, Blairy S, Del-Favero J, Dikeos D, Kaneva E, Lilli R, Massat I, Milanova V, Muir W, Noethen M, Oruc L, Petrova T, Papadimitriou GN, Rietschel M, Serretti A, Souery D, Van Gestel S, Van Broeckhoven C, Mendlewicz JM (2001): Variability of 5-HT2C receptor cys23ser polymorphism among European populations and vulnerability to affective disorder. Mol Psychiatry 6:579-585

Liao D-L, Yeh Y-C, Chen H-M, Chen H, Hong C-J, Tsai S-J (2001): Association between the Ser9Gly polymorphism of the dopamine D3 receptor gene and tardive dyskinesia in Chinese schizophrenic patients. Neuropsychobiology 44:95-98

Lovlie R, Daly AK, Blennerhassett R, Ferrier N, Steen VM (2000): Homozygosity for Gly-9 variant of the dopamine D3 receptor and risk for tardive dyskinesia in schizophrenic patients. Int J Neuropsychopharmacol 3:61-66

Lundstrom K, Turpin MP (1996): Proposed schizophrenia related gene polymorphism: expression of the Ser9Gly mutant human dopamine D3 receptor with the Semliki forest virus system. Biochem Biophys Res Comm 225:1068-1072

Macciardi F, Verga M, Cavallaro R, Pedrini S, Cohen S, Smeraldi E (1996): A genetic study of tardive dyskinesia in an Italian population of chronic schizophrenics. Psychiatr Genet 6:170

Macciardi F, Verga R, Pedrini S, Cavallaro R, Bongiorno F, Zanchi P, Lilli R, Smeraldi E (1997): Dopamine receptor genes and tardive dyskinesia. Am J Med Genet 74(6):626

Masellis M, Basile VS, Ozdemir V, Meltzer HY, Macciardi FM, Kennedy JL (2000): Pharmacogenetics of antipsychotic treatment: lessons learned from Clozapine. Biol Psychiatry 47:252-266

Meltzer WS, Newton JE, Steele RW, Claybrook M, Paige SR, McMillan DE, Hays S (1990): HLA antigens in TD. J Neuroimmunol 26(2):179-181

Ohmori O, Kojima H, Shinkai T, Terao T, Suzuki T, Abe K (1999): Genetic association analysis between CyP2D6*2 allele and tardive dyskinesia in schizophrenic patients. Psychiatry Res 87:239-244 
Ohmori O, Suzuki T, Kojima H. Shinkai T, Terao T, Mita T, Abe K (1998): Tardive dyskinesia and debrisoquine 4-hydroxylase (CYP2D6) genotype in Japanese schizophrenics. Schizophr Res 32(2):107-113.

Phillips PC (1998): The language of gene interaction. Genetics 149:1167-1171

Pickar D, Rubinow K (2001): Pharmacogenomics of psychiatric disorders. Trends Pharmacol Sci 22(2):75-83

Poolsup N, Li Wan Po A, Knight TL (2000): Pharmacogenetics and psychopharmacotherapy. J Clin Pharm Ther 25:197-220

Pritchard JK, Rosenberg NA (1999): Use of unlinked genetic markers to detect population stratification in association studies. Am J Hum Genet 65:220-228

Rietschel M, Krauss H, Muller DJ, Schulze TG, Knapp M, Marwinski K, Maroldt AO, Paus S, Grunhage F, Propping P, Maier W, Held T, Nothen MM (2000): Dopamine D3 receptor variant and tardive dyskinesia. Eur Arch Psychiatry Clin Neurosci 250:31-35

Risch NJ (2000): Searching for genetic determinants in the new millennium. Nature 405:847-856

Ritchie MD, Hahn LW, Roodi N, Bailey LR, Dupont WD, Parl FF, Moore JH (2001): Multifactor-dimensionality reduction reveals high-order interactions among estrogen-metabolism genes in sporadic breast cancer Am. J Hum Genet 69:138-147

Rosengarten H, Schweitzter JW, Friedhoff AJ (1994): Possible genetic factors underlying the pathophysiology of tardive dyskinesia. Pharm Biochem Behav 3:633-667

Roses AD (2000): Pharmacogenetics and the practice of medicine. Nature 405:857-865

Scharfetter J, Chaudhry HR, Hornik K, Fuchs K, Sieghart W, Kasper S, Aschauer HN (1999a): Dopamine D3 receptor gene polymorphism and response to clozapine in schizophrenic Pakastani patients. Eur Neuropsychopharmacol 10(1):17-20

Scharfetter J, Albus M, Hornik K, Fuchs R, Melamed G, Lesch F, Sieghart W, Kasper S, Aschauer HN (1999b): Association of tardive dyskinesia and dopamine D3 and D4 receptor gene polymorphism. Mol Psychiatry 4(Suppl 1):S85

Schooler NR, Kane JM (1982): Research diagnoses for tardive dyskinesia. Arch Gen Psychiatry 39:486-487

Schulze TG, Schumacher J, Muller DJ, Krauss H, Alfter D, Maroldt A, Ahle G, Maroldt A-O, Fernandez AN, Weber T, Held T, Propping P, Maier W, Nothen MM, Rietschel M (2001): Lack of association between a functional polymorphism of the cytochrome P450 1A2 (CYP1A2) gene and tardive dyskinesia in schizophrenia. Am J Med Genet 105:498-501

Segman RH, Neeman T, Heresco-Levy U, Finkel B, Karagacev L, Schlafman M, Durevich A, Yakir A, Lerner A, Shelevoy A, Lerer B (1999): Genotypic association between the dopamine D3 receptor gene and tardive dyskinesia in chronic schizophrenia. Mol Psychiatry 4:247-253

Segman RH, Heresco-Levy U, Finkel B., Inbar R, Neeman, T, Schlafman M, Dorevitch A, Yakir A, Lerner A, Shelevoy A, Lerer B (2000): Association between the serotonin 2C receptor gene and tardive dyskinesia in chronic schizophrenia: additive contribution of 5-HT2Cser and
DRD3gly alleles to susceptibility. Psychopharmacology 152:408-413.

Segman RH, Heresco-Levy U, Finkel B, Goltser T, Shalem R, Schlafman M, Dorevitch A, Yakir A, Greenberg D, Lerner A, Lerer B (2001): Association between the serotonin 2A receptor gene and tardive dyskinesia in chronic schizophrenia. Mol Psychiatry 6:225-229

Segman RH, Heresco-Levy U, Yakir A, Goltser T, Strous R, Greenberg D, Lerner A, Lerer B (2002): Interactive effect of cytochrome P450 17a-hydroxylase and dopamine D3 receptor gene polymorphisms on abnormal involuntary movements in chronic schizophrenia. Biol Psychiatry 51:261-263

Segman RH, Lerer B (in press): Genetic factors underlying drug induced tardive dyskinesia. In: Lerer B (ed), Pharmacogenetics of Psychotropic Drugs. Cambridge, Cambridge University Press

Segman RH, Lerer B (2002): Age and the relationship of dopamine $\mathrm{D} 3$, serotonin $2 \mathrm{C}$ and serotonin $2 \mathrm{~A}$ receptor genes to abnormal involuntary movements in chronic schizophrenia. Mol Psychiatry

Simpson GM, Lee JH, Zoubok B, Gardos G (1979): A rating scale for tardive dyskinesia. Psychopharmacology (Berl) 64:171-179

Smeraldi E, Zanardi R, Benedetti F, Di Bella D, Perez J, Catalano M (1998): Polymorphism within the serotonin transporter and antidepressant efficacy of fluvoxamine. Mol Psychiatry 3:508-511

Smith JM, Baldessarini RJ (1980): Changes in prevalence, severity, and recovery in tardive dyskinesia with age. Arch Gen Psychiatry 37:1368-1373

Sokoloff P, Giros B, Martres MP, Bouthenet ML, Schwartz JC (1990): Molecular cloning and characterization of a novel dopamine receptor (D3) as a target for neuroleptics. Nature 347:146-151

Steen VM, Lovlie R, McEwan T, McCreadie RG (1997): Dopamine D3 receptor gene variant and susceptibility to tardive dyskinesia in schizophrenic patients. Mol Psychiatry 2:139-145

Steimer W, Muller B, Leucht S, Kissling W(2001): Pharmacogenetics: a new diagnostic tool in the management of antidepressive drug therapy. Clinica Chimica Acta 308: 33-41

Tamminga CA, Dale JM, Goodman L, Kaneda H, Kaneda N (1990): Neuroleptic-induced vacuous chewing movements as an animal model of tardive dyskinesia: a study in three rat strains. Psychopharmacology (Berl) 102:474478

Tan E-C, Chong SA, Mahendran R, Dong F, Tan C-H (2001): Susceptibility to neuroleptic-induced tardive dyskinesia and the T102C polymorphism inthe serotonin type 2A receptor. Biol Psychiatry 144:147-150

Veenstra-VanderWeele J, Anderson GM, Cook EH Jr (2000): Pharmacogenetics and the serotonin system: initial studies and future directions. Eur J Pharmacol 410:165-181

Waddington JL, Youssef HA (1988): The expression of schizophrenia, affective disorder and vulnerability to tardive dyskinesia in an extensive pedigree. Br J Psychiatry 153:376-381

Weinhold P, Wegner JT, Kane JM (1981): Familial occurrence of tardive dyskinesia. J Clin Psychiatry 42:165-166 
Weiss KM, Terwilliger JD (2000): How many diseases does it take to map a gene with SNPs? Nat Genet 26:151-157

Woerner MG, Alvir JMJ, Saltz BL, Lieberman JA, Kane JM (1998): Prospective study of tardive dyskinesia in the elderly: rates and risk factors. Am J Psychiatry 155: 1521-1528

Yassa R, Ananth J (1981): Familial tardive dyskinesia. Am J Psychiatry 138:1618-1619

Yassa R, Jeste DV (1992): Gender differences in tardive dysk- inesia: a critical review of the literature. Schizophrenia Bull 18:701-715

Yousseff H, Lyster G, Youssef F (1989): Familial psychosis and vulnerability to tardive dyskinesia. Int Clin Psychopharmacol 4:323-328

Zahm DS, Brog JS (1992): On the significance of subterritories in the "accumbens" part of the rat ventral striatum. Neuroscience 50:761-767 